\title{
Microstructure and Mechanical Properties of Composites of Bovine Derived Hydroxyapatite (BHA) Reinforced with $\mathrm{MgF}_{2}$
}

\author{
MgF2 ile Güçlendirilmiş Sığır Kaynaklı Hidroksiapatit (BHA) Kompozitlerinin Mikroyapısı \\ ve Mekanik Özellikleri
}

\author{
Mustafa ŞENGÖR ${ }^{1}$ \\ ${ }^{1}$ Marmara Üniversitesi, Teknoloji Fakültesi Metalurji ve Malzeme Mühendisliği Bölümü, 34722, İstanbul, \\ Türkiye
}

\begin{abstract}
Composites of calcinated bovine bone derived hydroxyapatite (BHA) doped 1 and $2 \mathrm{wt} \% \mathrm{MgF}_{2}$ were prepared by a sintering process. Microstructure and crystallographic analyses along with measurements of density, compression strength, and microhardness were carried out in the produced samples. The experimental results indicated a beneficial effect of $\mathrm{MgF}_{2}$ in the matrix of BHA reflected in the significant increase of compression strength and microhardness up to $143 \mathrm{MPa}$ and $313 \mathrm{HV}$, respectively, achieved after sintering at $1300{ }^{\circ} \mathrm{C}$ for $2 \% \mathrm{MgF}_{2}$ addition. The presence of $\mathrm{MgF}_{2}$ reduced the onset of sintering towards lower temperatures (i.e. $1100{ }^{\circ} \mathrm{C}$ ) and increased the stability of hydroxyapatite towards transformation to TCP at 1300 ${ }^{0} \mathrm{C}$. The influence of $\mathrm{Mg}^{2+}$ and $\mathrm{F}^{-}$ions in the lattice of hydroxyapatite is discussed.

Keywords: Bovine derived hydroxyapatite; $\mathrm{MgF}_{2}$; sintering; mechanical properties; microstructure.

Öz

Kalsine edilmiş sığır kemiğinden elde edilen hidroksiapatit (BHA) ile ağırlıkça\% 1 ve ağırlıkça\% 2 MgF 2 katkılı kompozitleri bir sinterleme işlemi ile hazırlandı. Üretilen numunelerde mikroyapı ve kristalografik analizler ile birlikte yoğunluk, basma mukavemeti ve mikrosertlik ölçümleri yapıldı. Deneysel sonuçlar, $\% 2 \mathrm{MgF}_{2}$ ilavesi ve $1300^{\circ} \mathrm{C}^{\prime}$ de sinterlemeden sonra elde edilen BHA matrisin, sıkıştırma mukavemeti ve mikro sertlikteki önemli artı̧̧a (sırasıyla $143 \mathrm{MPa}$ ve 313 HV'ye kadar) neden olduğunu gösterdi. MgF2'nin varlığı, sinterleme başlangıcını daha düşük sıcaklıklara $\left(\sim 1100^{\circ} \mathrm{C}\right)$ düşürdü ve hidroksiapatitin $1300^{\circ} \mathrm{C}^{\prime}$ de TCP'ye dönüşüme karşı stabilitesini arttırdı. $\mathrm{Mg}_{2}{ }^{+}$ve $\mathrm{F}^{-}$iyonlarının hidroksiapatit örgüsündeki etkisi tartışıldı. Anahtar Kelimeler: Sı̆̆ır hidroksiapatiti; $\mathrm{MgF}_{2}$; sinterleme; mekanik özellikler; mikroyapı.
\end{abstract}

\section{INTRODUCTION}

The facts of life prolongation due to health care and the increase of sport and traffic accidents, in conjunction with the well-known intrinsic problems of autografts and allografts (e.g., availability, cost, viability, reproducibility), emerge the technology of biomaterials as to be of high social impact for the individuals, both elderly and young people, and the governments, especially the gross income of developed countries. In the case of hard-tissue prostheses and tissue engineering, hydroxyapatite $\left(\mathrm{HA}, \mathrm{Ca}_{10}\left(\mathrm{PO}_{4}\right)_{6}(\mathrm{OH})_{2}\right)$, that is the mineral of bones and teeth, is perhaps the most popular ceramic compound nowadays used in clinical applications, since it exhibits excellent biocompatibility and ability to establish direct bonding to natural bones. Comparing to synthetic HAs, biological apatites feature several substitutions at the $\mathrm{Ca}^{2+}, \mathrm{PO}_{4}{ }^{3-}$ and $\mathrm{OH}^{-}$sites of HA-lattice [1].

Composite materials with key bio-ceramic inclusions are preferred in many clinical applications. Bone is a composite structure of our body based on crucial element of HA and calcium phosphates. Synthetic, artificial bone composite materials usually used a host polymer with calcium phosphates. Some of the problems that will arise are due to the compatibility issues, osseointegration problems and mechanical performances [2].

As far as the application of HA in biomedicine is concerned, the brittle nature of HA limits its use only in coatings or low-load bearing applications. Accordingly, the reinforcement of HA matrix will expand the applications of this highly osseointegrating and conductive material. Reinforcing bioinert ceramics like $\mathrm{Al}_{2} \mathrm{O}_{3}, \mathrm{TiO}_{2}, \mathrm{ZrO}_{2}$ and $\mathrm{MgF}_{2}$ to increase mechanical performances of HA [3]. In the present study, the influence of $\mathrm{MgF}_{2}-\mathrm{doping}_{\text {(1-2 }}$ wt $\%$ ) on reinforcing sintered HA materials were investigated, where HA was derived from calcined bovine bone (BHA). The reinforcing effect of the dopant is assumed to be a result of the developed microstructure and the 
crystalline phases formed after sintering. Magnesium is a body-friendly material with an essential role in the human body [4], for instance at reducing risks of cardiovascular diseases, promoting catalytic reactions, controlling biological functions, and in the mineralization of calcined tissues. Approximately 60 to $70 \%$ of total body's $\mathrm{Mg}$-content is in the skeleton, as substitution ion in HA lattice. Approximately $0.38 \mathrm{wt} \%$ of cattle bone is $\mathrm{Mg}$ [4]. $\mathrm{Mg}^{2+}$ ions seemingly affect the conductivity of osteoclasts and osteoblasts [5]. Traces of $\mathrm{Mg}$ in natural bone affect cell adhesion and bone formation [6]. Hence, several compounds of $\mathrm{Mg}$ have been considered in biomedicine, such as bredigite $\left(\mathrm{Ca}_{7} \mathrm{MgSi}_{4} \mathrm{O}_{16}\right.$, considered as similarly bioactive to $\left.\mathrm{CaO}-\mathrm{SiO}_{2}\right)$, forsterite $\left(\mathrm{Mg}_{2} \mathrm{SiO}_{4}\right)$, and enstatite $\left(\mathrm{MgSiO}_{3}\right.$, considered as machinable biomaterial) [7].

With respect to HA composites, the presence of $\mathrm{Mg}$ in $\mathrm{HA}$ is related to apatite crystallization and stability, such as the thermal conversion to $\beta$-tricalcium phosphate ( $\left(-\mathrm{TCP}, \mathrm{Ca}_{3}\left(\mathrm{PO}_{4}\right)_{2}\right)$. Lim and Kim et al. doped $\mathrm{HA}$ with $1 \% \mathrm{MgO}$ [8], $\mathrm{MgF}_{2}$ and $\mathrm{CaF}_{2}$ [9] and found that substitution of $\mathrm{F}^{-}$for $\mathrm{OH}^{-}$caused an enhancing effect on cell culture tests. The same occurred in the case of $\mathrm{MgF}_{2}$ comparing to $\mathrm{CaF}_{2}$. From the same study, using $\mathrm{HA}-20 \% \quad \mathrm{Al}_{2} \mathrm{O}_{3}$ doped with $5 \%$ $\mathrm{MgF}_{2}$, HA-dissociation was entirely inhibited below $1400^{\circ} \mathrm{C}$. The effect of fluorine was also verified by Evis et al., in terms of increasing chemical stability, thermal stability and hardness, who produced HA-composites by doping with partially stabilized zirconia and $\mathrm{MgF}_{2}$ or $\mathrm{MgO}$ [10]. The presence of $\mathrm{MgF}_{2}$ in $\mathrm{HA}$ matrix favors the reduction of porosity of sintered bodies and the formation of secondary phases (i.e., $\alpha$-TCP) after sintering at $1400^{\circ} \mathrm{C}[11]$.

\section{MATERIALS AND EXPERIMENTAL PROCEDURE}

The powder of bovine derived hydroxyapatite, BHA, was produced according to the method described in earlier studies [12-17]. In brief, freshly cut femurs were deproteinized with $4 \mathrm{~N} \mathrm{NaOH}$ solution (48 h). After reirrigation, the samples were subjected to heat treatment at $850{ }^{\circ} \mathrm{C}$ for $4 \mathrm{~h}$ in open air to securely eliminate any risk of fatal disease transmission [18]. The calcinated BHA bulk pieces were properly ball-milled until fine $(<10 \mu \mathrm{m})$ BHA powder was obtained.

The BHA fine powder was mixed with 1 and $2 \mathrm{wt} \%$ $\mathrm{MgF}_{2}$ powder (Sigma Aldrich, 99.9\% purity, 3-6 mm particle size). The powder mixture was well homogenized by planetary ball-milling in acetone media using a zirconium oxide (yttrium stabilized) jar and balls (Retsch PM 100 SM 100, Haan, Germany). The resultant powders were well dried. Cylindrical pellets were prepared by uni-axially pressing at 350 $\mathrm{MPa}$ according to British Standard BS 7253. The green pellets were sintered at $1000,1100,1200$, and $1300{ }^{\circ} \mathrm{C}$ for $4 \mathrm{~h}$ in an open air furnace (Nabertherm HTC 3 /14,
Lilienthal, Germany) with heating and cooling rates of $5 \mathrm{~K} / \mathrm{min}$.

The compressive strength of the sintered samples was measured in a universal testing machine (Instron-8511, Norwood, MA 02062-2643, USA, displacement 2 $\mathrm{mm} / \mathrm{min}$ ). Their Vickers microhardness was measured in a Shimadzu testing unit (Shimadzu Inc., HMV-2, Japan, load 200 g). Density was measured by Archimedes method by employing a pycnometer (ULTRAPYC 1200e, Quantachrome, Boynton Beach, Florida 33426, USA). The presenting results were obtained from 10 different samples. The microstructure of the samples was observed in a field emission scanning electron microscope (FE-SEM, Hitachi S4100, Japan) under secondary electron mode (Figure1). The crystalline phases were identified by X-ray diffraction analysis (XRD, Rigaku Geigerflex D/Mac, $\mathrm{C}$ Series, Japan, $\mathrm{Cu} \mathrm{K}_{\mathrm{a}}$ radiation $1.5406 \mathrm{~nm}$ produced at $30 \mathrm{kV}$ and $25 \mathrm{~mA}, 2 \theta$ step $0.02 \%$ s).

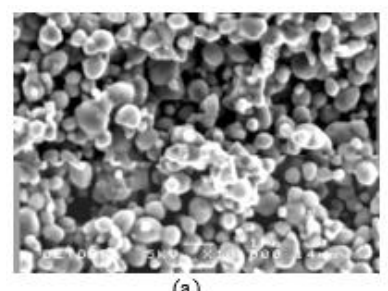

(a)

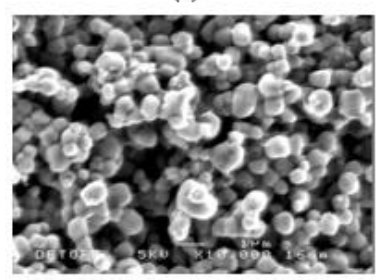

(c)

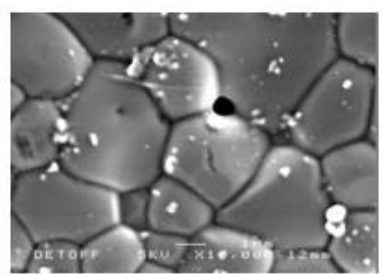

(b)

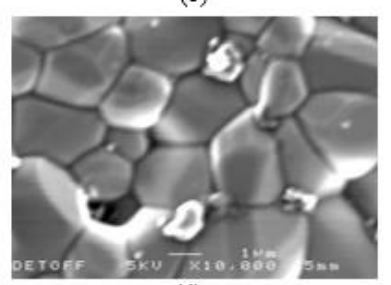

(d)
Figure 1. Microstructure of $\mathrm{BHA}-\mathrm{MgF}_{2}$ composites sintered at different temperatures: (a) BHA-1 wt $\%$ $\mathrm{MgF}_{2} 1000{ }^{\circ} \mathrm{C}$, (b) BHA-1 wt $\% \mathrm{MgF}_{2} 1300{ }^{\circ} \mathrm{C}$, (c) BHA-2 wt $\% \mathrm{MgF}_{2} 1000{ }^{\circ} \mathrm{C}$, (d) BHA- $2 \mathrm{wt} \% \mathrm{MgF}_{2}$ $1300{ }^{\circ} \mathrm{C}$.

\section{RESULTS AND DISCUSSION}

Table 1 presents the experimental results (and their standard deviation) of density (d), compressive strength $(\sigma)$, and Vickers microhardness (HV) of the produced $\mathrm{BHA}_{-\mathrm{MgF}_{2}}$ composites sintered at different temperatures. Tables 2 and 3 were prepared with results reported in earlier studies for similarly produced samples of BHA doped with $\mathrm{CaF}_{2}(0.5$ and $1.0 \mathrm{wt} \%)$ [19], and pure BHA [20]. Table 3 in conjunction with the results of earlier studies [21] indicates 1200 and $1300{ }^{\circ} \mathrm{C}$ as the optimum sintering temperatures with respect to the maximum strength of pure BHAmaterials obtained. The results of compressive strength of Table 1 indicate that doping of BHA with $\mathrm{MgF}_{2}$ shifts sintering onset towards lower temperatures. This effect is more pronounced in the case of lower (1 wt \%) amount of $\mathrm{MgF}_{2}$. This result has higher significance since the samples have still low densification degree at 
$1100{ }^{\circ} \mathrm{C}$, which means that there are porosity and little formation of glassy phase (due to eutectic melting) that closes the pores and increases microhardness. Therefore, if moderate compressive strength is required in a specific application, then $\mathrm{MgF}_{2}$-doping can result in a suitably strong scaffold of small porosity (i.e., low densification) that maintains all the features of calcinated BHA before the occurrence of the strong effect of extensive sintering.

Table 1. Influence of $\mathrm{MgF}_{2}$-content (1 and $2 \mathrm{wt} \%$ ) on density $(\mathrm{d})$, compression strength $(\sigma)$ and Vickers micro-hardness (HV) of BHA-MgF 2 composites sintered at different temperatures (the standard deviation of density was $\left.<0.001 \mathrm{~g} / \mathrm{cm}^{3}\right)$.

\begin{tabular}{|c|c|c|c|c|c|c|}
\hline \multirow{2}{*}{$\begin{array}{c}\mathbf{T} \\
\left({ }^{\circ} \mathbf{C}\right)\end{array}$} & \multicolumn{2}{|c|}{$\mathrm{d}\left(\mathrm{g} / \mathrm{cm}^{3}\right)$} & \multicolumn{2}{|c|}{$\sigma(\mathbf{M P a})$} & \multicolumn{2}{|c|}{ HV } \\
\hline & $\begin{array}{c}1 \\
\text { wt } \%\end{array}$ & $\begin{array}{c}2 \\
\text { wt } \%\end{array}$ & $\begin{array}{c}1 \\
\text { wt } \%\end{array}$ & $2 \mathrm{wt} \%$ & $\begin{array}{c}1 \\
\text { wt } \%\end{array}$ & $\begin{array}{c}2 \\
\text { wt\% }\end{array}$ \\
\hline 1000 & 2.181 & 2.156 & $\begin{array}{l}35.5 \\
\pm 2.1\end{array}$ & $\begin{array}{l}29.4 \\
\pm 6.6\end{array}$ & $\begin{array}{l}115 \\
\pm 94\end{array}$ & $\begin{array}{r}139 \\
\pm 7\end{array}$ \\
\hline 1100 & 2.281 & 2.165 & $\begin{array}{l}83.5 \\
\pm 8.6\end{array}$ & $\begin{array}{l}45.9 \\
\pm 7.0\end{array}$ & $\begin{array}{c}168 \\
\pm 15\end{array}$ & $\begin{array}{r}155 \\
\pm 13\end{array}$ \\
\hline 1200 & 2.611 & 2.446 & $\begin{array}{l}109.0 \\
\pm 3.1\end{array}$ & $\begin{array}{c}63.5 \\
\pm 15.6\end{array}$ & $\begin{array}{r}289 \\
\pm 14\end{array}$ & $\begin{array}{r}231 \\
\pm 14\end{array}$ \\
\hline 1300 & 2.976 & 2.884 & $\begin{array}{l}125.0 \\
\pm 4.5\end{array}$ & $\begin{array}{c}143.0 \\
\pm 27.48\end{array}$ & $\begin{array}{r}291 \\
\pm 14\end{array}$ & $\begin{array}{r}313 \\
\pm 22\end{array}$ \\
\hline
\end{tabular}

However, Table 1 shows that sintering successfully takes place at 1200 and $1300{ }^{\circ} \mathrm{C}$. The highest values of the measured magnitudes were obtained at $1300{ }^{\circ} \mathrm{C}$. This means that the glassy phase formed, due to the presence of $\mathrm{MgF}_{2}$ and the phenomenon of sintering itself, did not jeopardize the properties of the resultant composites, whereas the properties of pure BHA samples (Table 3) slightly decay at $1300{ }^{\circ} \mathrm{C}$ (than 1200 $\left.{ }^{0} \mathrm{C}\right)$. The presence of $\mathrm{MgF}_{2}$ should favor the formation of strong glassy phase at $1300{ }^{\circ} \mathrm{C}$ since the highest values of compression strength and hardness were achieved in the case of $2 \mathrm{wt} \% \mathrm{MgF}_{2}$ than $1 \%$. The slightly lower values of density in the samples with 2 wt $\%$ than 1 wt $\%$ may not represent poorer densification, but they are due to the lower density of $\mathrm{MgF}_{2}$ than BHA (so, the higher amount of $\mathrm{MgF}_{2}$ added, the lower density of the resultant composite densification results of BHA doped with the heavy $\mathrm{CaF}_{2}$, shown in Table 2, support this consideration).
Table 2. Influence of $\mathrm{CaF}_{2}$-content $(0.5 \%$ and $1.0 \%)$ on density $(\mathrm{d})$ and compression strength $(\sigma)$ of $\mathrm{BHA}-\mathrm{CaF}_{2}$ composites sintered at different temperatures reported in an earlier study [19].

\begin{tabular}{|c|c|c|c|c|}
\hline \multirow{2}{*}{$\begin{array}{c}\mathbf{T} \\
\left({ }^{\circ} \mathbf{C}\right)\end{array}$} & \multicolumn{2}{|c|}{$\mathrm{d}\left(\mathrm{g} / \mathrm{cm}^{3}\right)$} & \multicolumn{2}{|c|}{$\sigma(\mathbf{M P a})$} \\
\hline & $0.5 \%$ & $1.0 \%$ & $0.5 \%$ & $1.0 \%$ \\
\hline 1000 & $\begin{array}{c}2.893 \\
\pm 0.01\end{array}$ & $\begin{array}{l}3.117 \\
\pm 0.01\end{array}$ & $\begin{array}{l}31.8 \\
\pm 9.1\end{array}$ & $\begin{array}{r}15.4 \\
\pm 4.4\end{array}$ \\
\hline 1100 & $\begin{array}{c}3.002 \\
\pm 0.01\end{array}$ & $\begin{array}{c}3.074 \\
\pm 0.03\end{array}$ & $\begin{array}{l}42.7 \\
\pm 7.4\end{array}$ & $\begin{array}{r}16.7 \\
\pm 3.9\end{array}$ \\
\hline 1200 & $\begin{array}{c}3.152 \\
\pm 0.03\end{array}$ & $\begin{array}{c}3.134 \\
\pm 0.05\end{array}$ & $\begin{array}{c}48.3 \\
\pm 10.2\end{array}$ & $\begin{array}{c}28.2 \\
\pm 13.3\end{array}$ \\
\hline 1300 & $\begin{array}{c}3.026 \\
\pm 0.01\end{array}$ & $\begin{array}{c}3.183 \\
\pm 0.01\end{array}$ & $\begin{array}{c}35.5 \\
\pm 14.5\end{array}$ & $\begin{array}{r}36.0 \\
\pm 4.6\end{array}$ \\
\hline
\end{tabular}

In general, doping with $\mathrm{MgF}_{2}$ caused a considerable increase in compression strength and hardness of BHA. The low density of $\mathrm{MgF}_{2}$ and the small amount of $\mathrm{MgF}_{2}$ needed to achieve high mechanical properties are two extra advantages since the final implant material will be both strong and with low weight. The superior effect of $\mathrm{MgF}_{2}$ is clear by comparing the results of Table 1 with the poor mechanical properties of the BHA samples doped with $\mathrm{CaF}_{2}$, assuming the similar chemical nature of the two alkaline earth ions of $\mathrm{Mg}$ and $\mathrm{Ca}$.

Table 3. Mechanical properties (compression strength, $\sigma$ and Vickers micro-hardness, HV) of BHA samples sintered at different temperatures reported in earlier studies [20].

\begin{tabular}{ccccc}
\hline & \multicolumn{2}{c}{ BHA } & \multicolumn{2}{c}{ BHA } \\
\cline { 2 - 5 }$\left(\begin{array}{c}\mathbf{T} \\
\left({ }^{\mathbf{C}}\right)\end{array}\right.$ & $\begin{array}{c}\sigma \\
(\mathbf{M P a})\end{array}$ & $\mathbf{H V}$ & $\begin{array}{c}\sigma \\
(\mathbf{M P a})\end{array}$ & HV \\
\hline & & & 48.2 & 85.4 \\
1000 & $12 \pm 2$ & $42 \pm 2$ & \pm 20.0 & \pm 9.4 \\
& & & & \\
& & & 22.2 & 74.2 \\
1100 & $23 \pm 3$ & $92 \pm 4$ & \pm 5.1 & \pm 19.8 \\
& & & 75.2 & 148.5 \\
1200 & $67 \pm 7$ & $138 \pm 3$ & \pm 18.3 & \pm 10.5 \\
& & & & \\
& & & 65.0 & 130.7 \\
1300 & $62 \pm 11$ & $145 \pm 3$ & \pm 41.6 & \pm 17.9 \\
& & & & \\
\hline
\end{tabular}


From the literature, BHA-MgO composites sintered at $1300{ }^{\circ} \mathrm{C}$ have reached compression strength of 121.85 and 98.23 $\mathrm{MPa}$ [6] and microhardness of 305 and 218 $\mathrm{HV}$ [8] for 5 and $10 \% \mathrm{MgO}$, respectively. Evis et al. found that $\mathrm{HA}$ composites doped with $5 \% \mathrm{MgF}_{2}$ have higher hardness than those with $5 \% \mathrm{MgO}$ [11]. They postulated that the fluorine ions of $\mathrm{MgF}_{2}$ diffuse into the lattice of $\mathrm{HA}$ and result in increased thermal stability and mechanical properties of the sintered materials. Similar high values have been reported for BHA-TiO ${ }_{2}$ composites (at $1300{ }^{\circ} \mathrm{C} 105 \mathrm{MPa}$ and 204 $\mathrm{HV}$ for $5 \% \mathrm{TiO}_{2}$ and $247 \mathrm{HV}$ for $10 \% \mathrm{TiO}_{2}$, and at 1200 ${ }^{\circ} \mathrm{C} 104 \mathrm{MPa}$ for $10 \% \mathrm{TiO}_{2}$ ) [22]. However, the mechanism of reinforcement should be rather governed by the high chemical affinity of Ti to oxygen than the diffusion of the cation of titanium into HA lattice. Strong materials were fabricated when BHA was doped with inert glass (105 MPa for $5 \%$ glass at $1300{ }^{\circ} \mathrm{C}$ and $133 \mathrm{MPa}$ for $10 \%$ glass at $1200{ }^{\circ} \mathrm{C}$ ) [23]. Erkmen et al. have achieved $100 \mathrm{MPa}$ of compression strength in tooth-enamel derived-HA doped with partially stabilized zirconia [24].

The results of microstructure observations, shown in Fig. 1, and crystallographic analysis, shown in Fig. 2, agree with the above conclusions for the $\mathrm{BHA}-\mathrm{MgF}_{2}$ composites. The SEM images of Figs. 1a and 1c suggest a poor sintering regime at $1000{ }^{\circ} \mathrm{C}$, where the initial submicron powder particles of BHA are loosely connected one to the other. Sintering is complete at $1300^{\circ} \mathrm{C}$ (Figs. 1b and $1 \mathrm{~d}$ ). The corresponding X-ray diffractograms predominantly registered the patterns of apatite. Although the X-ray peaks of HA and fluorapatite (FA) are almost superimposed, the presence of fluorine (due to $\mathrm{MgF}_{2}$ ) in FA may be suggested due to the high mechanical properties of Table 1 (comparing to pure BHA of Table 2), since it is well known that fluorine reinforces HA. Peaks of isokite $\left(\mathrm{CaMgPO}_{4} \mathrm{~F}\right)$ can also be suggested. It is worthy noted that the produced materials exhibited remarkable thermal stability at $1300{ }^{\circ} \mathrm{C}$ since the peaks of apatite maintain their intensity. No peaks of TCP were registered at all, although the SEM images suggest intensive sintering. This stability was already indicated in the results of Table 1 . The low amount of $\mathrm{MgF}_{2}$ does not cause any perceptible difference between the samples having a different amount of $\mathrm{MgF}_{2}$ in either SEM-micrographs or X-ray diffractograms.

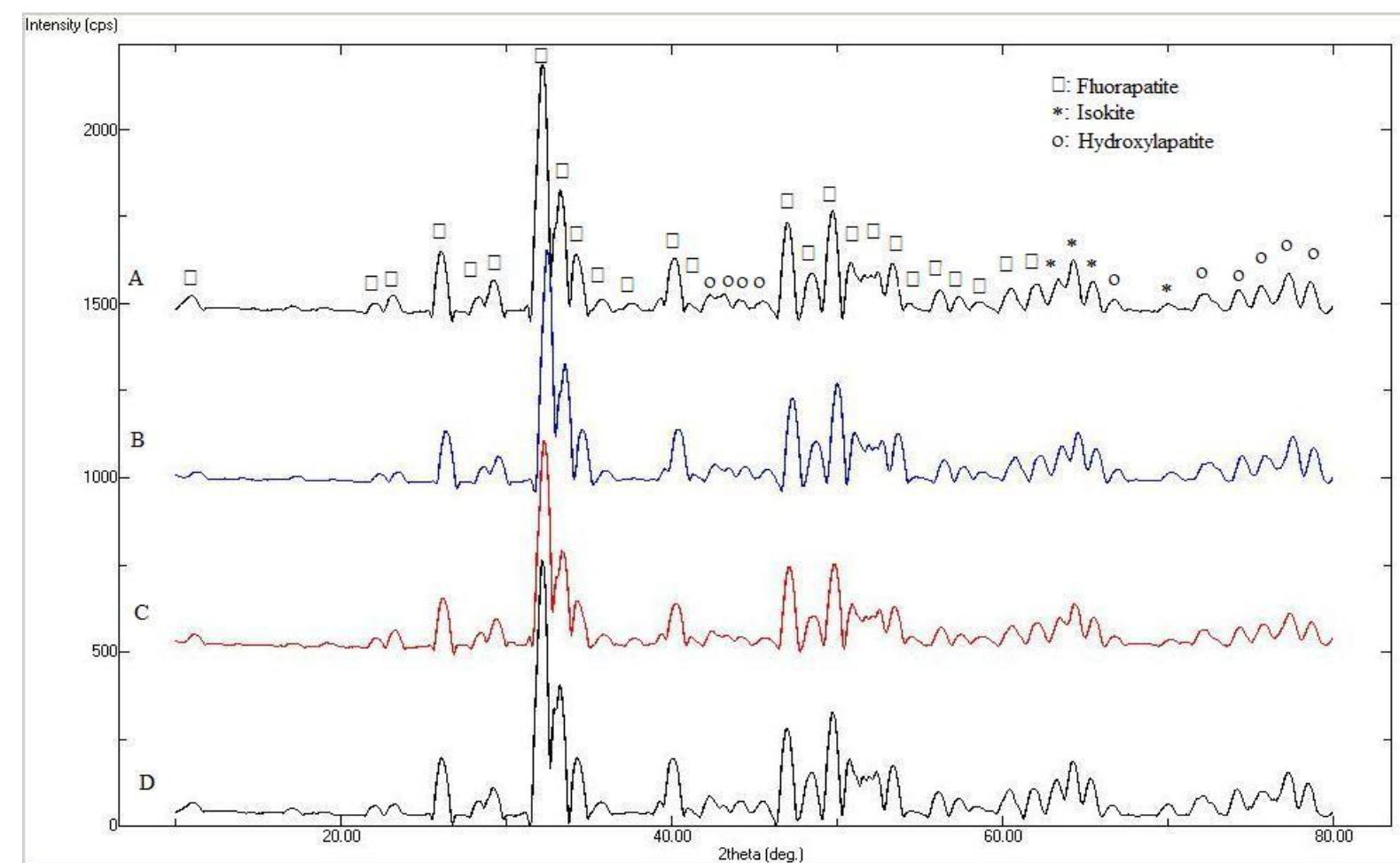

Figure 2. X-ray diffractograms of $\mathrm{BHA}-\mathrm{MgF}_{2}$ composites sintered at different temperatures: (A) BHA-1 wt $\%$ $\mathrm{MgF}_{2} 1000{ }^{\circ} \mathrm{C}$, (B) BHA-1 wt $\% \mathrm{MgF}_{2} 1300{ }^{\circ} \mathrm{C}$, (C) BHA-2 wt $\% \mathrm{MgF}_{2} 1000{ }^{\circ} \mathrm{C}$, (D) BHA-2 wt $\% \mathrm{MgF}_{2} 1300$ ${ }^{0} \mathrm{C}$. (The peaks have been identified with the ICDD cards: HA 84-1998; FA 15- 0876; Isokite $\left(\mathrm{CaMgPO}_{4} \mathrm{~F}\right) 7$ 0406).

In this study, naturally derived apatite (and not synthetic chemically produced HA) was intentionally selected, considering it as an economic, endlessly available, and designed by the nature herself material. Indeed, HA materials produced via powder processing route, where HA was obtained from bovine bone, has been proven that have great potential for bone substitute owing to their excellent biocompatible and osteoconductive properties [25]. Animal bones [26], teeth [27] as well as hydrothermally transformed 
aragonite skeletons of sea creatures [28] are abundant sources of naturally derived apatite. However, all the necessary safety precautions for eliminating all possible risks of transmitting incurable and fatal diseases from the animal-donors, such as human immunodeficiency virus (HIV), or bovine spongiform encephalopathy (BSE), should be taken [29]. Calcination method, as applied in this present study, makes the transmission of such prions impossible since no protein can survive at a high temperature of $850{ }^{\circ} \mathrm{C}$ for several hours [22].

The good results of the present study, in terms of the considerable increase of mechanical properties of BHA matrix by doping with only 1 and $2 \% \mathrm{MgF}_{2}$, indicate the produced composites for further consideration and experimentation in biomedicine, either in bulk or in coating (e.g., plasma-spray) form. These good results should be attributed to the influence of both the cation $\mathrm{Mg}^{2+}$ and the anion $\mathrm{F}^{-}$in apatite lattice. However, to shed light on the precise influence of these elements in apatite lattice (such as by Rietvelt analysis [30], that is beyond the scope of the present article), HA of high purity must be used, since biological apatites feature several substitutions in their lattice.

\section{CONCLUSION}

The results of this study showed that $\mathrm{MgF}_{2}$ could successfully dope the matrix of bovine derived hydroxypatite (BHA) since doping with only 1 and 2 wt\% $\mathrm{MgF}_{2}$ significantly increased the mechanical properties of BHA. The highest values of compression strength were achieved after sintering at $1300{ }^{\circ} \mathrm{C}: 143$ $\mathrm{MPa}$ for $2 \mathrm{wt} \% \mathrm{MgF}_{2}$ and $125 \mathrm{MPa}$ for $1 \mathrm{wt} \% \mathrm{MgF}_{2}$ addition. At the same sintering temperature, the highest $\mathrm{HV}$ values were obtained as $291 \mathrm{HV}$ for $1 \% \mathrm{MgF}_{2}$ and $313 \mathrm{HV}$ for $2 \% \mathrm{MgF}_{2}$. The effect of reinforcement should be attributed to the influence of both the cation $\mathrm{Mg}^{2+}$ and the anion $\mathrm{F}^{-}$in apatite lattice. Moreover, the experimental results suggest that the presence of $\mathrm{MgF}_{2}$ seemingly favors the shift of the onset of sintering towards lower temperatures (i.e. towards $1100{ }^{\circ} \mathrm{C}$ ) and increases the thermal stability of $\mathrm{HA}$ towards transformation to TCP at $1300{ }^{\circ} \mathrm{C}$.

\section{ACKNOWLEDGEMENTS}

I wish to very special thank Prof. Faik Nuzhet Oktar and Oguzhan Gunduz for supporting and also helping in this research.

\section{REFERENCES}

[1] Oktar, F.N., Yetmez, M., Agathopoulos, S., Lopez Goerne, T.M., Goller, G., Peker, I. and et al., (2006). Bond-coating in plasma-sprayed calcium-phosphate coatings. J Mater Sci: Mater in Med, 17, 1161-71.

[2] Moukbil, Y., Isindag, B., Gayir, V., Ozbek, B., Haskoylu, M. E., Oner, E. T., Oktar, F. N., Ikram, F., Sengor, M., \& Gunduz, O. (2020). 3D printed bioactive composite scaffolds for bone tissue engineering. Bioprinting, 17, e00064.

[3] Ibrahim, M., Labaki, M., Giraudon, J.-M., \& Lamonier, J.-F. (2020). Hydroxyapatite, a multifunctional material for air, water and soil pollution control: A review. Journal of Hazardous Materials, 383, 121139.

[4] Tiyyagura, H. R., Puliyalil, H., Filipič, G., Kumar, K. C., Pottathara, Y. B., Rudolf, R., Fuchs-Godec, R., Mohan, M. K., \& Cvelbar, U. (2020). Corrosion studies of plasma modified magnesium alloy in simulated body fluid (SBF) solutions. Surface and Coatings Technology, 385, 125434.

[5] Yamasaki, Y., Yoshida, Y., Okazaki, M., Shimazu, A., Kubo, T., Akagawa, Y., \& Uchida, T. (2003). Action of FGMgCO3Ap-collagen composite in promoting bone formation. Biomaterials, 24(27), 4913-4920.

[6] Cai, Y., Zhang, S., Zeng, X., Wang, Y., Qian, M., \& Weng, W. (2009). Improvement of bioactivity with magnesium and fluorine ions incorporated hydroxyapatite coatings via sol-gel deposition on Ti6Al4V alloys. Thin Solid Films, 517(17), 53475351.

[7] Jadidi, A., \& Salahinejad, E. (2020). Mechanical strength and biocompatibility of bredigite (Ca7MgSi4O16) tissue-engineering scaffolds modified by aliphatic polyester coatings. Ceramics International, 46(10, Part B), 1643916446.

[8] Oktar, F. N., Agathopoulos, S., Ozyegin, L. S., Gunduz, O., Demirkol, N., Bozkurt, Y., \& Salman, S. (2007). Mechanical properties of bovine hydroxyapatite (BHA) composites doped with $\mathrm{SiO} 2, \mathrm{MgO}, \mathrm{Al} 2 \mathrm{O} 3$, and $\mathrm{ZrO} 2$. Journal of Materials Science: Materials in Medicine, 18(11), 2137-2143.

[9] Kim, S.-J., Bang, H.-G., Song, J.-H., \& Park, S.Y. (2009). Effect of fluoride additive on the mechanical properties of hydroxyapatite/alumina composites. Ceramics International, 35(4), 16471650.

[10] Evis, Z., Usta, M., \& Kutbay, I. (2009). Improvement in sinterability and phase stability of hydroxyapatite and partially stabilized zirconia composites. Journal of the European Ceramic Society, 29(4), 621-628.

[11] Evis, Z., Usta, M., \& Kutbay, I. (2008). Hydroxyapatite and zirconia composites: Effect of $\mathrm{MgO}$ and $\mathrm{MgF} 2$ on the stability of phases and sinterability. Materials Chemistry and Physics, 110(1), 68-75.

[12] Oktar, F. N., K, K., \& E, P. (1999). Characterization of Processed Tooth Hydroxyapatite for Potential Biomedical Implant Applications. Artificial Cells, Blood Substitutes, and Biotechnology, 27(4), 367-379.

[13] Carvalho, A. L., Faria, P. E. P., Grisi, M. F. M., Souza, S. L. S., Taba Jr, M., Palioto, D. B., Novaes Jr, A. B., Fraga, A. F., Ozyegin, L. S., 
Oktar, F. N., \& Salata, L. A. (2007). Effects of Granule Size on the Osteoconductivity of Bovine and Synthetic Hydroxyapatite: A Histologic and Histometric Study in Dogs. Journal of Oral Implantology, 33(5), 267-276.

[14] Gunduz, O., Daglilar, S., Salman, S., Ekren, N., Agathopoulos, S., \& Oktar, F. N. (2008). Effect of Yttria-doping on Mechanical Properties of Bovine Hydroxyapatite (BHA). Journal of Composite Materials, 42(13), 1281-1287.

[15] Komur, B., Lohse, T., Can, H. M., Khalilova, G., Geçimli, Z. N., Aydoğdu, M. O., Kalkandelen, C., Stan, G. E., Sahin, Y. M., Sengil, A. Z., Suleymanoglu, M., Kuruca, S. E., Oktar, F. N., Salman, S., Ekren, N., Ficai, A., \& Gunduz, O. (2016). Fabrication of naturel pumice/hydroxyapatite composite for biomedical engineering. BioMedical Engineering OnLine, 15(1), 81 .

[16] Salman, S., Gunduz, O., Yilmaz, S., Öveçoğlu, M. L., Snyder, R. L., Agathopoulos, S., \& Oktar, F. N. (2009). Sintering effect on mechanical properties of composites of natural hydroxyapatites and titanium. Ceramics International, 35(7), 2965-2971.

[17] Gunduz, O., Erkan, E. M., Daglilar, S., Salman, S., Agathopoulos, S., \& Oktar, F. N. (2008). Composites of bovine hydroxyapatite (BHA) and ZnO. Journal of Materials Science, 43(8), 25362540 .

[18] Ozyegin, L. S., Oktar, F. N., Goller, G., Kayali, E. S., \& Yazici, T. (2004). Plasma-sprayed bovine hydroxyapatite coatings. Materials Letters, 58(21), 2605-2609.

[19] Ozyegin, L. S., Oktar, F. N., Agathopoulos, S., Salman, S., Bozkurt, Y., \& Eruslu, N. (2007). Improvement of Microstructure of Bovine Hydroxyapatite (BHA) by Doping with Calcium Fluoride. Bioceramics 19, 330, 43-46.

[20] Goller, G., Oktar, F. N., Agathopoulos, S., Tulyaganov, D. U., Ferreira, J. M. F., Kayali, E. S., \& Peker, I. (2006). Effect of sintering temperature on mechanical and microstructural properties of bovine hydroxyapatite (BHA). Journal of Sol-Gel Science and Technology, 37(2), 111-115.

[21] Gören, Ş., Gökbayrak, H., \& Altintaş, S. (2004). Production of hydroxylapatite from animal bone. Key Engineering Materials, 264-268, Issue III, pp. 1949-1952.

[22] Oktar, F. N. (2006). Hydroxyapatite-TiO2 composites. Materials Letters, 60(17), 22072210.

[23] Salman, S., Oktar, F. N., Gunduz, O., Agathopoulos, S., Öveçoğlu, M. L., \& Kayali, E. S. (2007). Sintering Effect on Mechanical Properties of Composites Made of Bovine
Hydroxyapatite (BHA) and Commercial Inert Glass (CIG). Key Engineering Materials, 330332, 189-192.

[24] Erkmen, Z. E., Genç, Y., \& Oktar, F. N. (2007). Microstructural and mechanical properties of hydroxyapatite-zirconia composites. Journal of the American Ceramic Society, 90(9), 2885-2892.

[25] Göller, G., \& Oktar, F. N. (2002). Sintering effects on mechanical properties of biologically derived dentine hydroxyapatite. Materials Letters, 56(3), 142-147.

[26] Mucalo, M. R. (2015). 14 - Animal-bone derived hydroxyapatite in biomedical applications. In M. Mucalo (Ed.), Hydroxyapatite (Hap) for Biomedical Applications (pp. 307-342). Woodhead Publishing.

[27] Kürkcü, M., Benliday1, M. E., Özsoy, S., Özyeğin, L. S., Oktar, F. N., \& Kurtoğlu, C. (2008). Histomorphometric evaluation of implants coated with enamel or dentine derived fluoridesubstituted apatite. Journal of Materials Science: Materials in Medicine, 19(1), 59-65.

[28] Rocha, J., Lemos, A. F., Sanjeevi, K., Agathopoulos, S., \& Ferreira, J. (2005). Hydroxyapatite Scaffolds Hydrothermally Grown from Aragonitic Cuttlefish Bones. Journal of Materials Chemistry, 15.

[29] Anderson, I., Mucalo, M., Johnson, G., \& Lorier, M. A. (2000). The processing and characterization of animal-derived bone to yield materials with biomedical applications. Part III. Journal of Materials Science. Materials in Medicine, 11, 743-749.

[30] Kannan, S., Goetz-Neunhoeffer, F., Neubauer, J., \& Ferreira, J. M. F. (2008). Ionic substitutions in biphasic hydroxyapatite and $\$ \beta \$$-tricalcium phosphate mixtures: Structural analysis by rietveld refinement. Journal of the American Ceramic Society, 91(1), 1-12.

\section{CAPTIONS OF FIGURES}

Fig. 1. Microstructure of $\mathrm{BHA}-\mathrm{MgF}_{2}$ composites sintered at different temperatures: (a) BHA-1 wt $\% \mathrm{MgF}_{2} 1000{ }^{\circ} \mathrm{C}$, (b) BHA-1 wt $\% \mathrm{MgF}_{2}$ $1300{ }^{\circ} \mathrm{C}$, (c) BHA-2 wt $\mathrm{MgF}_{2} 1000{ }^{0} \mathrm{C}$, (d) BHA- 2 wt $\% \mathrm{MgF}_{2} 1300{ }^{\circ} \mathrm{C}$.

Fig. 2. X-ray diffractograms of BHA-MgF composites sintered at different temperatures: (A) BHA-1 wt $\% \mathrm{MgF}_{2} 1000{ }^{\circ} \mathrm{C}$, (B) BHA-1 wt $\% \mathrm{MgF}_{2} 1300{ }^{\circ} \mathrm{C}$, (C) BHA-2 wt $\% \mathrm{MgF}_{2}$ $1000{ }^{\circ} \mathrm{C}$, (D) BHA-2 wt $\% \mathrm{MgF}_{2} 1300{ }^{\circ} \mathrm{C}$. (The peaks have been identified with the ICDD cards: HA 84-1998; FA 15- 0876; Isokite $\left(\mathrm{CaMgPO}_{4} \mathrm{~F}\right)$ 7-0406). 